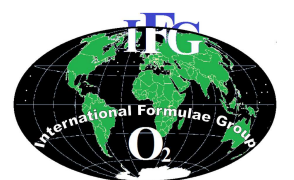

Available online at http://ajol.info/index.php/ijbes

Int. J. Biol. Chem. Sci. 8(3): 1239-1242, June 2014

International Joumal

of Biological and

Chemical Sciences

ISSN 1997-342X (Online), ISSN 1991-8631 (Print)

Short Communication

http://indexmedicus.afro.who.int

\title{
Assessment of some imported apple fruits (Malus domestica) commonly sold in Nigeria for alkaline and trace metal contents
}

\author{
Edmund OKORIE* and James OCHINIMHE \\ Department of Science Laboratory Technology, Federal Polytechnic Idah P.M.B. 1037 Idah, Kogi State, \\ Nigeria. \\ *Corresponding author ; E-mail: e.okorieslt@yahoo.com
}

\begin{abstract}
Three different apples were analysed for their heavy metal and alkaline metal contents. Results of this study using Flame Atomic Absorption Spectrophotometer and flame photometer indicated heavy metal ranges from $0.04-0.08 \mu \mathrm{g} / \mathrm{g}(\mathrm{Zn}), 3.20-3.70 \mu \mathrm{g} / \mathrm{g}(\mathrm{Pb}), 1.62-1.76 \mu \mathrm{g} / \mathrm{g}(\mathrm{Ni}), 0.09-0.21 \mu \mathrm{g} / \mathrm{g}(\mathrm{Cr}), 2.70-2.80$ $\mu \mathrm{g} / \mathrm{g}(\mathrm{Ca}), 0.37-0.52 \mu \mathrm{g} / \mathrm{g}(\mathrm{Fe}), 0.04-0.06 \mu \mathrm{g} / \mathrm{g}(\mathrm{Cd})$ and $0.12-0.17 \mu \mathrm{g} / \mathrm{g}(\mathrm{Cu})$. This study showed that $\mathrm{Pb}$, $\mathrm{Ni}, \mathrm{Cr}, \mathrm{Fe}$ and $\mathrm{Cu}$ have objectionable concentrations that are higher than the acceptable permissible limits by WHO. Cultivation of these apples may have occurred on polluted soils.

(c) 2014 International Formulae Group. All rights reserved.
\end{abstract}

Keywords: Flame photometer, apples, heavy metals, alkaline metals, AAS.

\section{INTRODUCTION}

Soil fertility is one of several factors, including light, moisture, weeds, insects, and diseases, that affect crop yield. An important part of crop farming is being able to identify and prevent plant nutrient deficiencies and toxicities. Plants require as much as 14 mineral elements for normal growth and reproduction. Each of these nutrients has a function in plants and is required in varying amounts in plant tissue. Micronutrients (nitrogen, phosphorus, potassium, calcium, magnesium and sulphur) are required in the largest amounts. Micronutrients (iron, copper, manganese, zinc, boron, molybdenum, chlorine and nickel) are required in relatively smaller amounts in plants. Other mineral elements that are beneficial to some plants but are not considered essential include sodium, cobalt, vanadium, selenium, aluminum and silicon. A deficiency occurs when an essential element is not available in sufficient quantity to meet the needs of the growing plant. Nutrient occurs when an element is in excess of plant needs and decreases plant or growth quality. Nutrient deficiency or toxicity symptoms often differ among species and varieties of plants (Gene et al., 2002). It is against this background that this study is aimed at assessing some imported apples in Nigerian market for their macro, micro and trace element compositions.

However, the intake of heavy metalcontaminated fruit and vegetables may pose a risk to human health; hence the heavy metal contamination of food is one of the most important aspects of food quality assurance (Radwan and Salama, 2006; Khan et al., 
2008). Heavy metals, in general, are not biodegradable, have long biological half-lives, and have the potential for accumulation in different body organs, leading to unwanted side effects (Järup, 2003; Sathawara et al., 2004). Plants take up heavy metals by absorbing them from airborne deposits on the parts of the plants exposed to the air from the polluted environments as well as from contaminated soils through root systems. Also, the heavy metal contamination of fruits and vegetables may occur due to their irrigation with contaminated water (Jassir et al., 2005; Elbagermi et al., 2012).

The aim of this research is to assess the quantity of trace and alkaline metals present in some imported apple fruits in Nigeria with a view to ascertaining their suitability for consumption.

\section{MATERIALS AND METHODS Sampling}

A total of three varieties of apple fruits were purchased from local supplies in Lagos city, Nigeria. They were then stored in plastic containers before being transported to Idah, Kogi State, Nigeria, for analysis.

\section{Materials}

The materials used are Flame photometer, Buck scientific AAS Model 210 AVG UK, muffle furnace, oven, mortar and pestle. All the chemicals or chemicals used are of analytical grade. The chemicals are $\mathrm{HNO}_{3}, \mathrm{H}_{2} \mathrm{SO}_{4}$. Distilled water was used in all preparations.

\section{Sample pretreatment}

The apple fruits were collected fresh, sundried for seven days after which they were oven-dried at $78{ }^{\circ} \mathrm{C}-80{ }^{\circ} \mathrm{C}$ for 24 hrs (Jones et al., 1991). The dried samples were grinded into fine powder using mortar and pestle. A known quantity of the sample was introduced into muffle furnace at a temperature of $550{ }^{\circ} \mathrm{C}$ for $4 \mathrm{hrs}$ until the sample was completely ashed. The ashed sample was cooled and stored in an air-tight container for digestion.

\section{Digestion}

Five gram of the ashed sample was weighed and digested with a mixture of $\mathrm{H}_{2} \mathrm{SO}_{4}$ and $\mathrm{HNO}_{3}$ in the ratio of $3: 1(50 \mathrm{ml}$ $\mathrm{HNO}_{3} ; 17.5 \mathrm{ml} \mathrm{H} \mathrm{SO}_{4}$ ). The digested samples were then made to the $100 \mathrm{ml}$ mark with distilled water for AAS analysis.

\section{RESULTS AND DISCUSSION}

The result of the analysis of some imported apple fruits commonly sold in Nigeria for trace and alkaline metal contents are indicated in Tables 1 and 2 respectively. These results are average of triplicate analysis.

The concentrations of $\mathrm{Cu}$ as shown in Table 1 are $0.08 \pm 0.01 \mu \mathrm{g} / \mathrm{g}, 0.06 \pm 0.04 \mu \mathrm{g} / \mathrm{g}$ and $0.04 \pm 0.01 \mu \mathrm{g} / \mathrm{g}$ for GA, GD and GS respectively. The WHO acceptable limit is $3.00 \mu \mathrm{g} / \mathrm{g}$ and therefore these values are within the range of acceptable limit. Zinc is an essential element for both plant and animal metabolism but only a small increase in its level beyond the acceptable limit may cause interference with physiological processes. Studies have shown that $\mathrm{Zn}$ is essential to neutralize the toxicity of $\mathrm{Cd}$ (Clarke, 2010). Lead concentrations are $3.60 \pm 0.02 \mu \mathrm{g} / \mathrm{g}$, $3.20 \pm 0.03 \mu \mathrm{g} / \mathrm{g}$ and $3.70 \pm 0.01 \mu \mathrm{g} / \mathrm{g}$ respectively for GA, GD and GS. The tolerable limit for $\mathrm{Pb}$ according to WHO standard is $0.01 \mu \mathrm{g} / \mathrm{g}$. Therefore, these high values of $\mathrm{Pb}$ are quite objectionable. Lead intake may constitute a serious risk to public health since it may show cognitive development, impaired intellectual performance in children and increases blood pressure and cardiovascular disease in adults. The concentrations of $\mathrm{Ni}$ as obtained are $1.62 \pm 0.02 \mu \mathrm{g} / \mathrm{g}, \quad 1.76 \pm 0.04 \mu \mathrm{g} / \mathrm{g}$ and $1.76 \pm 0.01 \mu \mathrm{g} / \mathrm{g}$ in GA, GD and GS 
respectively. The WHO limit for $\mathrm{Ni}$ in food is $0.02 \mu \mathrm{g} / \mathrm{g}$ indicating that the observed concentrations are quite objectionable. The known inherent effect of $\mathrm{Ni}$ poisoning is its carcinogenicity (WHO, 2004).

Observed $\mathrm{Cr}$ concentrations are $0.09 \pm 0.03 \mu \mathrm{g} / \mathrm{g}, \quad 0.21 \pm 0.06 \mu \mathrm{g} / \mathrm{g} \quad$ and $0.21 \pm 0.01 \mu \mathrm{g} / \mathrm{g}$ for GA, GA and GS respectively. WHO acceptable limit is 0.05 $\mu \mathrm{g} / \mathrm{g}$ indicating that the $\mathrm{Cr}$ content of the analysed apples are above this limit. Chromium occurs naturally in many fruits and vegetables and it is an essential micronutrient for humans and shortages may cause heart conditions, disruption of metabolism and diabetes. However, overexposure to $\mathrm{Cr}$ beyond the acceptable limit may lead to skin rashes, ulcer, respiratory problems, weakened immune system, kidney and liver damage (Demirezen and Aksoy, 2006). The concentration of $\mathrm{Ca}$ ranged from $2.70 \pm 0.07$ $\mu \mathrm{g} / \mathrm{g}-2.80 \pm 0.01 \mu \mathrm{g} / \mathrm{g}$. This range falls within the acceptable limit suggested by WHO. Calcium is essential in the bone development (Ching et al., 2008). The observed Fe concentrations are slightly above the WHO limits of acceptance with a range of $0.37 \pm 0.05$ $\mu \mathrm{g} / \mathrm{g}-0.52 \pm 0.01 \mu \mathrm{g} / \mathrm{g}$. The presence of Fe in the apple fruit varieties can be attributed to the fact that they are important micronutrients for various metabolic functions of the plant (Demirezen and Aksoy, 2006).
Cadmium concentrations ranged from $0.04 \pm 0.01 \mu \mathrm{g} / \mathrm{g}-0.06 \pm 0.01 \mu \mathrm{g} / \mathrm{g}$. This is slightly above the WHO limits $(0.04 \mu \mathrm{g} / \mathrm{g})$ in GA and GD samples. Excessive $\mathrm{Cd}$ intake constitutes a risk to humans since it may induce kidney dysfunction, skeletal damage and reproductive disorder (Hennrich, 2002). Copper concentrations in the three different apples ranged from $0.12 \pm 0.01 \mu \mathrm{g} / \mathrm{g} \quad$ $0.17 \pm 0.02 \mu \mathrm{g} / \mathrm{g}$. These are within the WHO acceptable limits of $1.0 \mu \mathrm{g} / \mathrm{g}$. Apart from its function as a biocatalyst, $\mathrm{Cu}$ is necessary for the body pigmentation, maintenance of a healthy central nervous system and for the prevention of anaemia. It is also inter-related with the functions of $\mathrm{Zn}$ and $\mathrm{Fe}$ in the body (Ching et al., 2008).

The results obtained using Flame Photometer (FP) in the detection of $\mathrm{Na}$ ranged from $63 \mu \mathrm{g} / \mathrm{g}-69 \mu \mathrm{g} / \mathrm{g}$, while the WHO limit is $200 \mu \mathrm{g} / \mathrm{g}$. Sodium is highly needed in the body to provide active transport of nutrient in a cell. Sodium balances fluids in the body. It is needed for muscle concentrations and influences blood pressure. Even modest reduction in $\mathrm{Na}$ consumption can lower blood pressure. Potassium concentration ranged from $144 \mu \mathrm{g} / \mathrm{g}-165 \mu \mathrm{g} / \mathrm{g}$. The WHO limit of acceptability is $50 \mu \mathrm{g} / \mathrm{g}$. These $\mathrm{K}$ concentrations are far above the limits.

Table 1: concentration of heavy metals in three apple fruits $(\mu \mathrm{g} / \mathrm{g})$.

\begin{tabular}{|c|c|c|c|c|c|c|c|c|}
\hline \multirow[t]{2}{*}{ Sample } & \multicolumn{8}{|c|}{ Parameters in $\mu \mathrm{g} / \mathrm{g}$} \\
\hline & Zn & $\mathbf{P b}$ & $\mathbf{N i}$ & $\mathrm{Cr}$ & Ca & $\mathbf{F e}$ & Cd & $\mathbf{C u}$ \\
\hline $\begin{array}{l}\text { Gala } \\
\text { apple(GA) }\end{array}$ & $0.08 \pm 0.01$ & $3.60 \pm 0.02$ & $1.62 \pm 0.02$ & $0.09 \pm 0.03$ & $2.80 \pm 0.01$ & $0.38 \pm 0.01$ & $0.05 \pm 0.01$ & $0.17 \pm 0.04$ \\
\hline $\begin{array}{l}\text { Golden } \\
\text { delicious } \\
\text { apple (GD) }\end{array}$ & $0.06 \pm 0.04$ & $3.20 \pm 0.03$ & $1.76 \pm 0.04$ & $0.21 \pm 0.06$ & $2.82 \pm 0.01$ & $0.52 \pm 0.01$ & $0.06 \pm 0.01$ & $0.15 \pm 0.01$ \\
\hline $\begin{array}{l}\text { Granny smith } \\
\text { apple (GS) }\end{array}$ & $0.04 \pm 0.01$ & $3.70 \pm 0.01$ & $1.76 \pm 0.01$ & $0.21 \pm 0.01$ & $2.70 \pm 0.07$ & $0.37 \pm 0.05$ & $0.04 \pm 0.01$ & $0.12 \pm 0.01$ \\
\hline WHO limits & 3.00 & 0.01 & 0.02 & 0.05 & 10.00 & 0.30 & 0.40 & 1.00 \\
\hline
\end{tabular}

$\mathrm{WHO}=$ World Health Organization. 
Table 2: Concentration of $\mathrm{Na}$ and $\mathrm{K}$ using flame photometer.

\begin{tabular}{lcc}
\hline Samples & \multicolumn{2}{c}{ Parameters in $\boldsymbol{\mu g} / \mathbf{g}$} \\
\cline { 2 - 3 } & $\mathbf{N a}$ & $\mathbf{K}$ \\
\hline Gala apple (GA) & 69 & 156 \\
Golden delicious apple (GD) & 63 & 165 \\
Granny smith apple (GS) & 65 & 144 \\
WHO limits & 200 & 50 \\
\hline
\end{tabular}

\section{Conclusion}

From the results and discussions obtained, it was observed that $\mathrm{Pb}, \mathrm{Ni}, \mathrm{Cr}, \mathrm{Fe}$ and $\mathrm{Cu}$ are higher in concentrations than the acceptable limits posed by WHO. This is an indication that the apples may have been grown on contaminated soils or affected by irrigation with contaminated water. It is essential for the nature of soils and irrigation water be studied before being used for agricultural purposes. The risk assessment associated with the consumption of these apples would be very high in view of the associated inherent health risks.

\section{REFERENCES}

Al Jassier MS, Shaker A, Khaliq MA. 2005. Deposition of heavy metals on green leafy vegetables sold on roadsides of Riyadh City, Saudi Arabia. Bull. Environ. Contamin. Toxicol., 75(5): 1020-1027.

Ching JA, Briag CA, Alejandro GJD. 2008. Uptake and distribution of some heavy metals in Peanut (Arachis hypogaea) grown in artificially contaminated soils. Phillipine Agric. Sci., 91: 134-142.

Clark B. 2010. Apple Cup Pivals Contribute to Apple Genome Sequencing. Washington State University: Washington.

Demirezen D, Aksoy A. 2006. Heavy metal level in vegetables in Turkey. J. Food Qual., 3: 252-265.

Elbagermi MA, Edwards HGM, Alajtal AI. 2012. Monitoring of heavy metyal contentys in fruits and vegetables collected from production and market sites in the Misurata area of Libya. ISRN Anal. Chem., 2012: 1-5.

Gene S, Peter M, Peter S, Manjula N, David D. 2002. Integrated Pest Management: Crop Nutrient Deficiencies and Toxicities. University of MissouriColumbia Publishers: Missouri.

Hennrich C. 2002. Magic, mushroom in religion and Alchemy. Rochester: Park Street Press 64-70. Herodotus Histories, 1: 191.

Järup L. 2003. Hazards of heavy metal contamination. British Medical Bulletin, 68: $167-182$.

Jones JB Jr, Wolf B, Mills H. 1991. Plant Analysis Handbook, Micro-Macro Publishing Inc.: Athens, GA; 23-26.

Khan S, Cao Q, Zheng YM, Huang YZ, Zhu YG. 2008. Health risks of heavy metals in contaminated soils and food crops irrigated with wastewater in Beijing, China. Environ. Pollut., 152(3): 686-692.

Radwan MA, Salama AK. 2006. Market basket survey for somen heavy metals in Egyptian fruits and vegetables. Food Chem. Toxicol., 44(8): 1273-1278.

Sathawara NG, Parikh DJ, Agarwal YK. 2004. Essential heavy metals in environmental samples from Western India. Bull. Environ. Contamin. Toxicol., 73(4): 756-761.

WHO. 2004. World Health Organization Guidelines for Drinking Water Quality. World Health Organization. 